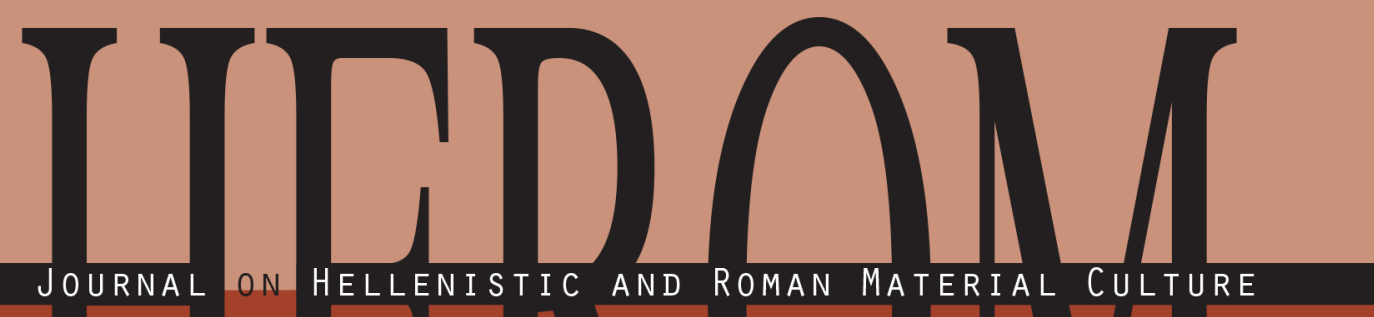

VOLUME 4, ISSUE 1, 2015 
HEROM 


\section{Editors}

Jeroen Poblome, Daniele Malfitana and John Lund

\section{Scientific Committee}

S.E. Alcock (Brown University), P.M. Allison (University of Leicester), D. Bernal Casasola (Universidad de Cádiz), M. Bonifay (Centre Camille Jullian - UMR 6573, CNRS), R. Brulet (Université Catholique de Louvain), L. Chrzanovski (International Lychnological Association), F. D’Andria (Università di Lecce), A. Berlin (Boston University), I. Delemen (Istanbul University), M. de Vos (Università di Trento), K. Dunbabin (McMaster University), M. Feugère (Equipe TPC - UMR 5140, CNRS), I. Freestone (Cardiff University), C. Gasparri (Università di Napoli "Federico II"), E. Giannichedda (Università degli Studi di Milano), A. Hochuli-Gysel (Fondation Pro Aventico, Avenches), S. Ladstätter (Österreichisches Archäologisches Institut), M. Lawall (University of Manitoba), D. Manacorda (Università di Roma Tre), S. Martin-Kilcher (Universität Bern), D. Mattingly (University of Leicester), D. Michaelides (University of Cyprus), M.D. Nenna (Maison de l'Orient et de la Méditerranée, Lyon), M. O’Hea (University of Adelaide), E. Papi (Università di Siena), D.P.S. Peacock $\dagger$ (University of Southampton), J.T. Peña (University of California, Berkeley), F. Pirson (Deutsches Archäologisches Institut Istanbul), N. Rauh (Purdue University), P. Reynolds (University of Barcelona), S. Rotroff (Washington University in St. Louis), G.D.R. Sanders (American School of Classical Studies at Athens), K.W. Slane (University of Missouri-Columbia), F. Slavazzi (Università degli Studi di Milano),V. Stissi (Universiteit van Amsterdam), M. Torelli (Università di Perugia), P. Van Dommelen (Brown University), H. von Hesberg (Deutsches Archäologisches Institut Rome), A. Wilson (University of Oxford)

The journal is open to international research submitted by individual scholars as well as by interdisciplinary teams, and especially wishes to promote work by junior researchers and new and innovative projects. Challenging research themes can be explored in dedicated issues, and theoretical approaches are welcomed. Book reviews and review articles further screen the pulse of the field.

For editorial guidelines, please contact the editors Jeroen Poblome (University of Leuven - jeroen.poblome@arts.kuleuven.be), Daniele Malfitana (IBAM-CNR Italy - daniele. malfitana@cnr.it) or John Lund (The National Museum of Denmark - john.lund@natmus.dk).

For more information, visit www.herom.be. 


\section{HEROM}

\section{JOURNAL ON HELLENISTIC and Roman material Culture}

VOLUME 4 - ISSUE 1 - 2015

\section{Edited by}

Jeroen Poblome

Daniele Malfitana

John Lund 
From 2015 onward HEROM appears biannually in May and November.

Online ISSN: 2294-4281

Print ISSN: 2294-4273

Subscription options:

* Institutional online only

* Institutional online \& print

* Individual online only

* Individual online \& print

Non-subscribers options:

* Pay-per-view online article

* Print copy

Journal available online at

www.ingentaconnect.com/content/LUP/HEROM

(C) 2015 by Leuven University Press / Presses Universitaires de Louvain / Universitaire Pers Leuven. Minderbroedersstraat 4, B-30oo Leuven (Belgium).

All rights reserved. Except in those cases expressly determined by law, no part of this publication may be multiplied, saved in an automated datafile or made public in any way whatsoever without the express prior written consent of the publishers.

$\mathrm{D} / 2015 / 1869 / 30$

NUR: 682

Lay-out: Jurgen Leemans

Cover: Friedemann 


\section{CONTENTS}

Herom Shows its True Colours! Editorial Preface

Jeroen Poblome, John Lund and Daniele Malfitana

Ceramics, Foodways and Local 'Sub-Cultures' in North-Western Iberia at the Height of the Roman Empire: The Castro Do Vieito Case Study

António José Marques da Silva

Dovecotes from the Roman and Byzantine Periods: An Overview 33

Sophia Germanidou

Body Piercing during the Late Iron Age: The Case of Roman Amphorae from Toulouse (France)

Matthew E. Loughton

Laurence Alberghi

Turning over a New Leaf: Leaf Impressions of Styrax Officinalis

L. and Vitis Vinifera L. on Late Roman Sagalassos Amphorae

Philip Bes

Leo Vanhecke

Instructions to authors 


\title{
HEROM SHOWS ITS TRUE COLOURS!
}

\section{EDITORIAL PREFACE}

\author{
Jeroen Poblome, John Lund and Daniele Malfitana \\ UNIVERSITY OF LEUVEN, THE NATIONAL MUSEUM OF DENMARK, AND IBAM- \\ CNR-ITALY
}

One of the privileges of editing HEROM is that our publisher, Leuven University Press, kindly allows us to help choose the colour of the cover. This year's colour we find pretty. Not that the others were bad, also considered as a set, but the 2015 hue, value and chroma - to put it in Albert H. Munsell's terms - are particularly lively. Fittingly so.

Indeed, HEROM is alive and kicking: as of 2015 two issues will be published annually, in the months of May and November of each year. In part this is a managerial decision, to continue to create a place for HEROM as a journal, but this new step also reflects the growing amount of contributions which are being proposed for consideration on Hellenistic, Roman and late antique material culture. This is nothing less than excellent news, as scholars of the past are increasingly becoming aware of how studies of material culture, broken though it may be, are oftentimes instrumental in grounding theory and concepts, archaeological or other-disciplinary, in the reality of the past. It also works the other way round, by allowing the study of the minutiae of past material culture, still the bread and butter of much classical archaeology, to meaningfully reach a wider audience, and in doing so surpass the ad hoc and often coincidental nature of the collections and assemblages we study.

As editors - as well as practitioners in this field - we cannot be alone in considering that every archaeological project, be it survey, excavation or even non-fieldwork-based, no matter how big or small in enterprise, dealing with aspects of the Hellenistic to late antique worlds, holds a variety of material culture, which represents considerable potential still to be unlocked. As ever 
more archaeologists wish to be encompassing, inspirational and inclusive in explaining the human experiences of past communities, studies of material culture increasingly take centre-stage. And rightfully so. HEROM wishes to continue to function as a medium to voice concerns and issues in the study of ancient material culture, but much more so to demonstrate the potential of our evidence to contribute to a historically meaningful understanding of the past.

António José Marques da Silva's contribution is an excellent example of this ambition. The collection of material culture he presents is very much early Roman Imperial in nature. At face value. But to truly understand material culture one needs only to scratch the surface in order to discover how disconcertingly stubborn such evidence can be, pulling interpretations in many ways, without much sense of direction. That is where theoretical concepts come in, in this case mainly the originally linguistic notion of creolisation, in order to help create meaning to basically mixed messages, experiences and practices.

Sophia Germanidou offers an overview of dovecotes from the late Roman and Byzantine periods. Pigeon breeding structures represent the study of material culture in its widest sense. These features, documented in a range of historical, art historical and archaeological sources, do not necessarily conform to typically mobile material culture, such as pottery, glass vessels or objects cut from bone, but are mostly lost in the gap between architectural and material culture studies. Yet, transport amphorae were at times secondarily used as dovecotes. To be sure, this gap is a scholarly artefact, corresponding to no reality in the past, which is one of the reasons why HEROM wishes to bring this contribution.

The next two contributions deal with specific aspects of material culture remains, and as it happens both concern amphorae. Matthew Loughton and Laurence Alberghi consider the practices of piercing and holing amphorae, based on the study of an assemblage excavated recently at Toulouse. Basically from holes, useful observations can be derived on the nature and function of the studied site, as well as on the origins of some of the people who lived and worked there. It is illustrative of the potential of material culture studies that not only the objects an sich need to be considered, but also each and every detail of these. When properly documented, it is easy to grasp how seemingly odd features reveal past practices of daily life, possibly involving multiple uses of the same object.

Philip Bes and Leo Vanhecke, finally, do not deal with prototypical and well-known categories of amphorae. Their study concerns amphorae made 
in the immediate vicinity of the Pisidian town of Sagalassos. The degree to which the scholarly world does not know these types of products seems to be related to their unknown and possibly very restricted range of distribution. Who produces amphorae in a mountainous region at quite a distance from the sea or other transport options anyway? The paper does not so much wish to attract attention to the existence of the Sagalassos amphorae per se, but demonstrates how detailed observation of basically oddities on these vessels reveals ancient practices. Even if the latter can only be interpreted in hypothetical terms, the various options indicate the intricacies of past reality of the associated chaine(s) opératoire(s).

HEROM 4.2 will present another series of individual studies. On the other hand, both issues planned for 2016 will feature thematic approaches. One will be dedicated to the memory and intellectual legacy of Professor David Peacock, who sadly passed away in March this year. He is and will be much missed, also on HEROM's scientific committee. The other 2016 issue will present a collection of contributions documenting the 'material turn' in the discipline of Geography, and the ways in which this represents an analytical as well as conceptual potential for the disciplines of the past. 